\title{
STATE ASSUMPTION OF NOMINATION AND ELECTION EXPENSES*
}

No one doubts the propriety of the assumption by the State of some of the expenses incident to an election of State officers. It has always been our uniform practice, and is defensible on any theory of the proper functions of representative government.

The worth of any such scheme of political organization is largely determined by the character and aims of those who direct its operations. They must be men who understand, and mean to further, the true interests of the people over whom they may be placed in authority. To see that they are so placed only after a reasonable opportunity to ascertain what manner of men they are, and then only by the free choice of their fellow citizens, is, therefore, one of the first objects of every constitutional scheme.

The American people have become satisfied that a free choice is best secured by a secret ballot. To make it secret, the State must take some part in its preparation. To have it, at all, the State must lay out money to secure lists of qualified voters and to provide ballot boxes and election officers. So far its duty is incontestable.

But it would be idle to call for votes in any State-wide election, unless there were known candidates for or against whom to cast them.

The State recognizes this by printing, or authorizing the printing, on the ballots which it prepares the names of the candidates; but it is not its business to select these. The selection belongs to the people, or to a recognized part of them. The business of the State is to make sure that the names printed on the ballot are the result of such a selection. It may permit a substitution of other names in writing, at the will of any voter; but he takes it for himself, and with no reference to representative or collective action.

The main subject of the ballot will be the choosing of the names submitted by others for the consideration of the voter.

$\mathrm{He}$ will generally be a member of a certain political party. He will generally desire to vote for the candidates put forward by

* This article was originally prepared for and read before the East Conference of Governors. 
that party. The State should respect that desire by giving him a fair opportunity to satisfy it, at least as to non-judicial appointments.

This cannot be, unless the official ballot contains the names of all that his party has placed in nomination. The State may, therefore, fairly inquire into what each political party has done in this direction, and whether it has been fairly done. "Let me control the nominations," some one has said, "and I care not who makes the elections." To secure fair party action, the State may regulate the holding of party conventions, so far as their end may justify such interference. It may require returns by party officials of the nominations made. It may require the appointment of such officials for that purpose, and prescribe the form of their returns. It may exercise its police power to preserve order in nominating assemblies. These things cost money; but thus far there will be little dispute that the State may go, and should go.

But now we enter on debatable ground. May the State properly assume all or any of such expenses as individuals are now at, in attempting to secure a nomination for office?

They are expenses which bear most heavily on the particular persons specially interested. A campaign for a nomination to be made by a party convention is a personal affair. It does not strictly concern the party itself. It is a contest within the party. The cost of the struggle falls upon the man seeking the nomination, and his special friends. It is often so great that he abandons the struggle. The obvious tendency of this is to shut out the poor man, unless he puts himself under what they would be apt to consider implied obligations to those who supply him with the necessary funds. I regard this, however, as an inevitable incident of party government, whether in respect to party conventions or direct primaries within a party.

A direct primary not restricted to a party choice, but where the whole body of the voters may participate, without any limitations, by reason of their party affiliations, stands on a different ground. Here, in theory, the whole people give two days every year or two, to the election of their rulers, one to select names for consideration, and another to choose between those thus put forward.

The State can certainly not be expected to assume the cost of circulating papers for the nomination of any particular per- 
son. He may have no sort of fitness for the office. Notoriously these papers are often signed by those who never seriously intended to vote for the candidate whom they thus endorse. Often, it is to be feared, the signatures are bought. At a congressional primary in Boston a few years ago, a certain candidate got in all not one-eighth as many votes as there were signatures to his nominating papers.

But on the other hand, a primary open to the whole people, and called to present names for the approval of the whole people, seems a just subject of governmental aid, as respects to whatever makes for the end that it was established to secure.

We may agree in theory with Aristotle's saying that no man should ask for an office, but he who is fit for it ought to have it, whether he wishes the position or not. This was the aim our fathers had in view, when they devised the electoral colleges for the selection of the President and Vice-President of the United States. Their scheme worked fairly well in respect to the first choice-Washington; but it broke completely down in the contest which finally resulted in the election of Jefferson. It ignored the practical necessity of party government wherever there are representative institutions. Some one must give more than two or three hours, or two or three days in a year to the business of electing men to public office. There must be many who do, and many of different views, or the best results will not be worked out.

It is true that much of this will not take place in the open. A few will lead the rest, and the rest will hardly know where they are being led. A former president of Harvard University said some forty years ago: "I always feel, when I put my hand to the ballot box, that I am being used by somebody, I know not whom, for some purpose, I know not what." He had himself to blame for it.

Parties indeed create the problem which we are considering, but they are well worth their cost. They keep the currents of public opinion in motion. Abolish them, and there will be stagnation. In some form, and by some means, if they do not control, they will always seriously affect nominations for State and national office.

A political party is an organization of men for two objects: to secure the enforcement by the government of certain rules of political action, and to put in office men on whom it may rely 
to see that these rules are enforced. The first object is the primary one, and no one doubts that it offers a legitimate reason for the existence of parties in a free State. The second object is fairly incidental to the first, and concerns the proper working of the government, almost, if not quite, as nearly.

The government, therefore, must have a right, in self-defense, so to regulate the making of nominations, whether by party conventions, or primaries, or by direct primaries of the whole people, as, not to dictate the choice, but to assure that it fairly represents the desires of those who make it.

For more than a quarter of a century our States have been passing statutes to regulate proceedings in party nominating processes. Massachusetts was one of the first to set the example.

This was, in effect, a fundamental change in our political system; but the courts have supported it as a reasonable incident to legislative power.

So far as concerns direct primaries that are state-wide and not simply affairs of party, the State must have a right, if the people are satisfied that such nominations by a party convention or primary can be replaced by another mode of proceeding, which gives them a better opportunity to make their wishes prevail, to institute this other mode.

And what the State can institute, it can protect.

The people may fairly be given, in our country, three lines of opportunity. First, to determine the ends they wish their governments to secure; second, to determine, as to all large matters, the means by which those ends can be best attained; and third, to choose the men to put their conclusions into proper shape, and to administer the State in conformity thereto.

As to the small matters, the selection of means seems to me to belong of right to their representatives. The people can pass to advantage on large questions, not on small ones.

And now another question calls for answer.

After deciding what expenses may fairly be met from public money, how much of the money should come direct from the funds of the State, and how much from local communities?

The State must certainly settle by law or some form of regulation, the kinds of expenses, which it is fit to make a public charge. It can hardly, with safely, let that be decided by city or county authorities. They might be too easily swayed, upon occasion, by local pressure from personal friends or political 
associates. Wherever there is a question as to spending public money to discharge what would otherwise be an individual or party liability, no barrier can be wisely let down which can serve to protect the interests of the mass of the community against those of a comparatively small part of it.

The State must, then, definitely fix the lines of expense. Home rule must be confined in this respect to directing how the outlay shall be made; and at what cost, within the lines so prescribed.

It cannot be unfair to allow certain kinds of expenditure in State primaries or elections, which are not authorized at municipal primaries and elections, and the converse is equally true. A municipal newspaper, for instance, such as the city of Los Angeles, California, published for a few months, might be allowable as a means of popular enlightenment in local political affairs, although a State newspaper, to circulate in every kind of local community, some representing one description of productive industry, and others another, hardly could be.

Expenses of this kind; chargeable by law on municipal funds, have already reached in some States, quite startling figures. The increasing use of the direct primary and the recall, both for State and muncipalities, adds greatly to what had been previously regarded as the only proper political expenditures.

Printers bills especially must be large. Thus in the proposed charter of 1913 for the city of Dayton, Ohio, any elector desiring to invoke the process of recall must (Section 14) obtain blank petitions from the clerk of the city commission of a certain form, and this clerk is "to keep a sufficient number of such blank petitions on file for distribution." No limit is or could be placed on the number to be thus kept on hand.

The discussion thus far has been confined to what the State may spend or permit her local political agencies to spend; but this is closely linked to the consideration of what may be spent from private funds, either for similar or for different purposes.

There can be no doubt that the State can and should confine such outlay to a few subjects, and to a fixed and reasonable sum. Without such laws, the man of small means is put at a disadvantage, and corruption is, in many cases, inevitable. With them, the assumption of these outlays by the public treasury would be brought much more within or near the range of practical and well-ordered politics. 
We do not want a property qualification for every public office, either directly or indirectly.

In 1882, Gen. James B. Weaver, was named by the populists as their candidate for President of the United States, in the free silver campaign of that year. He was a man of little property, and must have known that he had no real chance of an election. He had to borrow money enough to enable him to meet his first speaking appointment which was at Denver. After his address at that meeting, a woman who sympathized with his views, took the platform and said that money was needed to prosecute such a campaign, and that the party treasury was empty. She would, therefore, propose taking a collection then and there in silver dollars, and added that anyone desiring to contribute might throw a dollar at her. Instantly there came such a shower of silver dollars as to threaten the safety of all upon the platform, and, I may add, to give assurance that he could continue what he had thus begun. But every impecunious candidate is not one who shines upon the platform, or who has a quick-witted woman to help him over the financial shoals. The State must help him by keeping party expenditures within narrow limits.

A common expedient, and one generally approved as we know, is to keep the amount that any candidate can expend within a certain sum proportionate to the number of electors who, if they chose, could vote for him. Twenty years ago Missouri adopted this plan, making the limit a cent for each vote cast at the last election for the same office.

Several States name a flat sum constituting an invariable limit. Minnesota, for instance, prescribes $\$ 7,000$ as such a limit for a candidate for Governor, and a third of a year's salary in case of minor local officials.

Under the present scheme, by which the State meets but a small part of the expenses of its electoral machinery, it may be sufficient to provide that no items shall be included except a candidate's own personal travel, postage and telegraph bills; hall rent; hire of speakers and musicians; printing and advertising; copying poll-lists; canvassing voters; providing challengers; and the legal fees for filing papers.

The cost, which has often been large, of hiring transportation of electors to the polls would be thus excluded, and rightly. It often brings an unworthy element to the polls, and the case of 
the old and feeble can be fairly well provided for, as in Belgium, by increasing the number of polling places.

But the State ought not to pay for all that a candidate might find it convenient to expend, even for the purposes which I have specifically enumerated, and within a narrow limit of total cost. It could fairly, I think, go as far as to prohibit any campaign expenditures by or for any party or candidate for nomination or for office, provided it assumed the entire cost of both nomination and election proceedings in the following matters:

1. Printing and distribution of ballots and other papers required by law.

2. Travelling expenses of the candidates to and from appointments for meetings incident to the campaign, whether public or private.

3. Travelling expenses of speakers in their behalf to and from public meetings.

4. Copying poll or registry lists.

5. Providing challengers.

Whether it should assume it, is a question which will not be here discussed. Of the items above named the cost of the first would probably be the greatest. It is an expense which several States have already undertaken to meet, in whole or part. It has become not uncommon to mail a sample ballot, in advance of the election, to each elector. In California a card of instructions as to the mode of voting goes with it. The sample ballot is on paper of a different color from that of the real official ballot. California also mails to each voter at a Presidential election a biographical sketch of each of the -candidates. It is prepared by the candidate himself or, with his consent, by the proper committee of his party. It cannot exceed three hundred words in length, and when presented to the State authorities must be accompanied by a payment of $\$ 200.00$.

The cost of the necessary postage, under such laws, is, of course, very considerable. This has led Michigan to forbid the mailing of campaign cards, or other political advertising matter, though they can be otherwise distributed, within certain limits. of size. She also prohibits advertising by the publication of purely campaign newspapers.

The second item represents a reasonable and proper course of proceeding on the part of the candidate. He must have a 
fair opportunity to appear before his constituents, and to consult with his political supporters.

The third item is more questionable, but seems also a necessary kind of outlay. It will be observed that it does not include any compensation for services.

To the fourth item there seems little room for objection. The candidate or his backers need to refer often to the official list of voters, were it only for a guide, as he and they go from house to house or cast up the prospects of success.

The fifth item is not less necessary. It is the plain interest of the State that only those duly qualified should vote, and that to secure this, it should be some one's duty to scrutinize the registration lists with care.

The cost to the public of all this would be very considerable. It seems to me, therefore, that for whatever the State may thus pay out, it should partly re-imburse itself by refusing to put any name on the official election ballot, unless paid a registration fee proportionate to the number of votes cast for the office in question at the last election. Without seeking to make these fees so large as fully to indemnify the public treasury, they should be large enough to discourage nominations not proceeding from leading parties or schools of political thought, but representing merely personal ambitions.

If it be once granted that it is wise for the State to regulate the holding of party primaries, it becomes logical that they should pay the necessary expenses. Thus far no State, I believe, does this, though some pay part of it, and provide for the balance by a pro rata assessment on the candidates for nomination.

Charging these with official fees to a reasonable amount seems particularly proper in States where the only struggle is for the nomination, and the election is almost perfunctory, calling out but a minority of the voters, although a large majority may participate in the previous primaries.

Missouri charges a fee on the filing of a nomination paper, but sends it to the party treasury.

Assessing any such expense by a State law upon candidates would, of course, be impracticable as respects offices of the United States.

Oregon and North Dakota each pay the travelling expenses of delegates to the national nominating conventions of established parties to an amount not exceeding $\$ 200.00$ for each. I should 
regard this as unnecessary. The interesting nature of the proceedings of such a body, and the opportunities it gives to meet political associates, are sure to attract attendance from almost all those who receive the compliment of an election, and are sincere and intelligent members of the party.

The study which has been thus presented of the subject assigned to me for discussion, suggests one question of fundamental character.

Are all our modern additions to the machinery of election worth what they cost us? The Professor of Comparative Legislation at Harvard University, and author of the standard work on American statute law, Frederick J. Stimson, is of the opinion that direct primaries, the regulation by law of caucuses, modes of nomination, and the filing of nomination papers, the compelling those nominated to stand for election, unless they formally resign, and the refusal of official recognition to parties not casting a certain percentage of votes at some previous election, are one and all mistakes in government, with the possible exception of allowing public nomination papers. $\mathrm{He}$ is not alone in the view thus taken but, be he right or wrong, the expenditure which these things entail should certainly be closely watched.

The Chicago Bureau of Public Efficiency recently published a report on "The Growing Cost of Election in Chicago and Cook County." It advocates the curtailing, or if that prove insufficient, the abolition of municipal and judicial primaries, simply on the ground of expense. This for Chicago has trebled in sixteen years, reaching in 1912 almost a million dollars, which is more than the whole civil list expenditure of the United States during the first year after the adoption of the national constitution.

There is no one of us, I presume, who has not had occasion to remark upon the multiplication in his State of the amounts of legislative appropriations. The world moves; our States grow. The duties of the State increase. So does necessarily the cost of public service. All this admitted, our States generally are spending more than they need spend. One of the richest and largest of them, on July 1st, 1913, had before it for payment during the balance of the year, over thirty-five million dollars, and, with less than half a million on hand, was threatened with a deficit of ten million dollars before the year closes.

Is it worth while for them to assume further burdens in the direction which has been considered? There is a bottom even to a State treasury. 
I have intimated that State regulation of party nominations might logically call for the State assumption of proper nomination expenses. Some States, as has been seen, have already made a beginning towards the undertaking of this function. Still stronger grounds exist in favor of State assumption of all election expenses. But to Anglo-Saxons, and hardly less to the composite American of our day, logic does not seem to have much to do with political science. We advance-or slip backa step at a time. Practice crowds theory aside.

In some of our States public opinion expects far more from the government than in others. These will experiment for the benefit of all.

New Haven, Conn.

Simeon E. Baldwin. 